\title{
DIVERGENT EFFECTS OF NATURAL SELECTION ON TWO CLOSELY-RELATED POLYMORPHIC SNAILS
}

\author{
BRYAN CLARKE* \\ Department of Zoology, University Museum, Oxford
}

Received 3r.x.59

\section{INTRODUCTION}

THE shells of land snails of the genus Cepaea Held. display striking colour and banding polymorphisms which have attracted the attention of many workers, particularly as supposed examples of random variation. Cain and Sheppard (1954) have shown, however, that the proportions of different varieties in colonies of Cepaea nemoralis L. can be related to the colour and uniformity of the background. They explain this relation, but not the maintenance of the polymorphism itself, in terms of selective visual predation, which has been demonstrated by Sheppard (1951).

Lamotte (I95I) admits the existence of visual selection, but regards it as unimportant. The most cogent of his arguments is that he can find no correlation between the variations in $C$. nemoralis L. and $C$. hortensis Müll. living together in mixed colonies. The two species are almost identical in appearance, show a similar range of phenotypes, and seem to share the same predators. Lamotte reasons that if visual predation were important in determining the proportions of phenotypes, the two species should show parallel variation. They do not. Cain and Sheppard argue that this result does not necessarily contradict their hypothesis. The consequences of visual predation may be influenced by the non-visual selective values of the various phenotypes, values that are unlikely to be the same in both species. Small differences in ecology or behaviour might also result in a different pattern of selection, even from the same predator.

The work described in this paper is a study of the distribution of phenotypes in natural populations of Cepaea hortensis and an attempt to make clear the differences between its polymorphism and that of Cepaea nemoralis.

\section{METHODS}

During I957 and 1958, I collected random samples of $C$. hortensis from sixty-four colonies, most of them within sixty miles of Oxford. Localities were selected for diversity of vegetation and background. Where possible, several widely separated habitats of the same type were studied. During sampling the area was searched carefully to avoid collecting only those snails that were most obvious to the eye.

The snails were scored for age, condition (live, dead predated, or dead unpredated), colour and banding :-

\section{(i) Age}

Snails whose lips had not yet formed were classed as juveniles. Those with complete or incomplete lips were considered to be adult.

* Present address : Department of Zoology, West Mains Road, Edinburgh 9. 


\section{(ii) Condition}

In order to prevent duplication, broken shells were scored only if they displayed more than half the lip. Shells broken by thrushes could usually be distinguished from those predated by small mammals (see Morris, 1954).

\section{(iii) Colour}

In $C$. hortensis the colour of the shell varies from almost pure white to a very dark greenish-black, but the commonest colours are white, yellow, pink and brown (see Taylor, 1914). The first two colours (var. alba Picard and var. lutea Picard) are often difficult to separate, and appear to have every sort of intermediate between them. I have included them both in the "yellow" class. The pink forms (var. incarnata Picard) and the "browns" (var. baudonia Moquin-Tandon and var. olivacea Taylor) can more easily be distinguished. Shells of the latter group have a pale violet ground-colour which is modified by the overlying periostracum so that they appear brown. It is probable that Taylor's var. lilacina is a brown that has a very pale periostracum.

\section{(iv) Banding}

The shell may have up to five bands running along the whorls (very rarely six or more). The bands are usually dark brown in colour. A form in which they

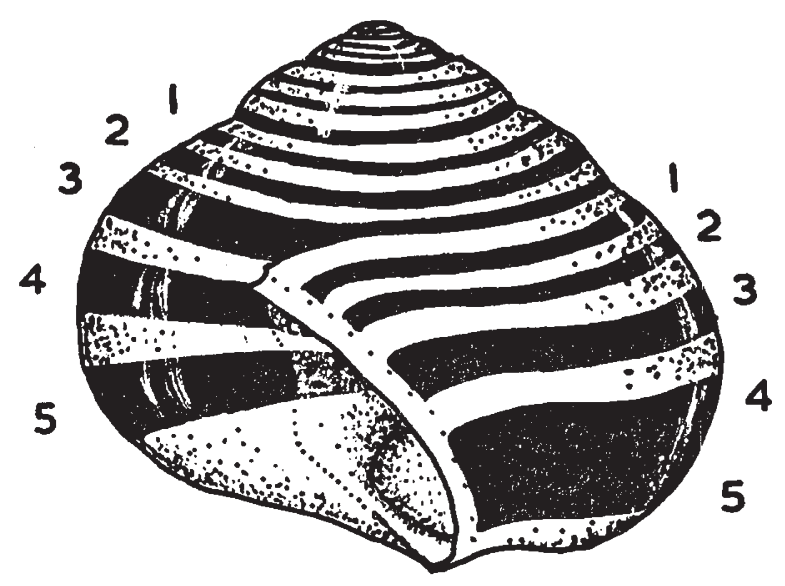

Frg. 1.-A shell of $C$. hortensis, showing the method of numbering the bands. On the righthand whorl, bands 4 and 5 are fused.

are translucent and unpigmented on a pale yellow or white ground-colour (var. arenicola MacGillivray) occurs among my collections, usually as a distinct type. In some samples, however, there is a general tendency for the bands to be pale or partially pigmented (var. lurida Moquin-Tandon), and intermediates occur between normal banding and the unpigmented condition. Collections showing more than Io per cent. of such forms are recorded with an asterisk, but the individual shells, unless completely unpigmented, are scored as normal.

For recording, the bands are numbered I, 2, 3, 4 and 5 from the top of the whorl downwards (see fig. I). Absence of a band is recorded by 0 , and fusions are signified by bracketing the numbers representing the fused bands (e.g. (12) 3(45), o23(45) etc.). Following Cain and Sheppard (1950) I have not regarded bands as fused unless they are joined for at least $90^{\circ}$ round the whorl from the lip. Fusions are not scored in young snails. Bands occurring only as a faint trace near the lip are not recorded as present. They are very rare. 
I have grouped the habitats from which samples were taken into six classes.

(i) Grass. This includes open chalk downlands as well as a number of roadside habitats in which grass predominates. The background is usually a uniform light green. In long grass it may be darker, but still fairly uniform.

(ii) Hedgerowes and rough herbage. This class comprises open roadside habitats in which grass does not predominate. The vegetation is often mixed, and may include nettles (Urtica dioica L.), brambles (Rubus sp.), willowherb (Epilobium spp.), ivy (Hedera helix L.), hawthorn and various umbellifers. The background is generally darker and less uniform than in the grassy habitats.

(iii) Beechwoods. These are all escarpment woods of pure beech, or beech and ash. C. hortensis is not common within them, but tends to occur where there is some ground vegetation. The collections from Maidensgrove and Savernake were taken in patches of rosebay willowherb (Epilobium angustifolium L.), those from Clipper Down, Hackpen and Aston Rowant in stinging nettles, and the Ward's Hurst sample was collected from low brambles. The Knoll Down group are small beech clumps-each less than a hundred yards across, and each surrounded by downland grass. At Knoll Down B the ground flora within the clump itself is predominantly grass. There is less grass at Knoll Down A, and hardly any at all in Knoll Down C. In the beechwood areas, whatever the ground vegetation, there is a layer of leaflitter which gives a dark background. I have not found hortensis in plateau beechwoods, although nemoralis is often present.

(iv) Other deciduous woods. This is a heterogeneous class, including all those woods that do not fit into the last category. Boarstall Wood is predominantly oak, Uffington is oak and hawthorn. Derry Hill Great Wood is open beech with ash and conifers. Wychwood, Rockley Copse, Guiting Wood and Elsfield Covert are very mixed, with hawthorn, oak, ash and hazel. Elsfield Covert, in addition, is damp and boggy, with clumps of Equisetum. In all cases the snails were collected in areas of dense ground vegetation, generally either willowherb or nettles. The background is usually less dark and less uniform than in the beechwood areas. Elsfield, however, is very dark indeed.

(v) Fens. Samples were taken in three calcareous fens. The collecting areas at Marcham and Headington Wick are in long rushes, and the backgrounds are uniform dark brown. Shippon is greener and much more varied, with grass, nettles, and other herbage.

(vi) Ivy. The collections included here were taken beneath ivy (Hedera helix L.). The background is very dark brown, almost black; the earth being bare and shaded by a close cover of ivy leaves. Beckley is the most uniform habitat. At Cassington and Mickleham the areas of ivy are fringed by grass. At Mickleham and Woodcote there is some penetration of the cover by umbellifers. The Sonning sample was collected from a bank of ivy within a mixed beech and ash wood.

\section{RESULTS}

The composition of samples is given in tables $\mathrm{I}$ and 2. Only live and predated adults are included. Young shells are not used in the tables because fusions of bands cannot be scored among them. Unbroken dead adults are excluded because the mode of death is not known, and therefore the direction of possible errors cannot be predicted (see below). Furthermore, in one colony-Dragons Hill-the dead unbroken shells showed a significantly higher proportion of banded forms than did the live adults $(\mathrm{p}<0.005)$.

Among my samples, no significant differences were observed between live and predated adults. This does not, of course, argue against the hypothesis of visual selection by predators. A force of 
TABLE $1-$ The composition of

\begin{tabular}{|c|c|c|c|c|c|c|c|c|c|c|c|c|c|c|c|}
\hline$(a)$ & & & & & & & & & & & & & $(f)$ & (g) & (h) \\
\hline & & & & & & & & ks & Bro & & & & 8 & & \\
\hline Locality & & & 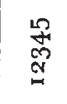 & $\begin{array}{l}\stackrel{0}{\circ} \\
\stackrel{8}{0}\end{array}$ & $\begin{array}{l}8 \\
8 \\
8\end{array}$ & 遌 & 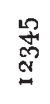 & 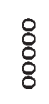 & 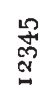 & $\begin{array}{l}\& \\
\$\end{array}$ & 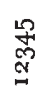 & & $\underset{⿱ 亠 凶}{\circ}$ & 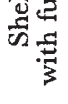 & Total \\
\hline Grass & & & & & & & & & & & & & & & \\
\hline I. Silbury Hill, A & & • & I 59 & $\cdots$ & 70 & 2 & ... & $\cdots$ & 27 & 2 & $\cdots$ & ... & & 143 & 260 \\
\hline 2. Silbury Hill, B & & & 83 & $\cdots$ & $3^{2}$ & $\ldots$ & $\cdots$ & $\cdots$ & 5 & 2 & $\ldots$ & $\cdots$ & $\cdots$ & $5^{\circ}$ & 122 \\
\hline 3. Silbury Hill, C & . & & $4^{6}$ & $\cdots$ & $4^{I}$ & $\cdots$ & $\cdots$ & 2 & 2 & $\cdots$ & $\cdots$ & ... & $\cdots$ & 12 & $9^{I}$ \\
\hline $\begin{array}{l}\text { 4. Silbury Hill, D } \\
\text { 5. Dragons Hill }\end{array}$ & · & & $\begin{array}{l}53 \\
60\end{array}$ & $\cdots$ & $\begin{array}{r}23 \\
259\end{array}$ & $\cdots$ & $\begin{array}{l}\cdots \\
\ldots\end{array}$ & $\begin{array}{l}\cdots \\
\ldots\end{array}$ & $\begin{array}{r}\mathrm{I} \\
\ldots\end{array}$ & $\ldots$ & $\ldots$ & $\begin{array}{l}\cdots \\
\ldots\end{array}$ & $\cdots$ & $\begin{array}{r}5 \\
25\end{array}$ & 78 \\
\hline 6. Walker's Hill & • & & 7 & $\cdots$ & $\begin{array}{r}39 \\
22\end{array}$ & ... & $\cdots$ & $\cdots$ & $\cdots$ & $\dddot{1}$ & $\cdots$ & $\cdots$ & $\cdots$ & $\begin{array}{l}25 \\
1\end{array}$ & $\begin{aligned} 323 \\
30\end{aligned}$ \\
\hline 7. Morgan's Hill & . & & 14 & $\cdots$ & 9 & 4 & $\cdots$ & Io & $\cdots$ & $\cdots$ & $\cdots$ & $\cdots$ & $*$ & Io & 37 \\
\hline $\begin{array}{l}\text { 8. Three Barrows } \\
\text { 9. The Ball, Pewsey }\end{array}$ & & & $\begin{array}{l}19 \\
29\end{array}$ & $\ldots$ & $\begin{array}{l}55 \\
32\end{array}$ & $\cdots$ & $\cdots$ & $\cdots$ & $\begin{array}{c}3 \\
\ldots\end{array}$ & $\begin{array}{c}2 \\
\ldots\end{array}$ & $\cdots$ & $\cdots$ & $\cdots$ & 7 & 79 \\
\hline Io. Chisledon-Ogbourn & & & 161 & $\cdots$ & 142 & 6 & $\ldots$ & 7 & 3 & 2 & 4 & $\cdots$ & $\cdots$ & 5 & 325 \\
\hline II. Wheatley $\cdot$ & & & 80 & $\ldots$ & $4^{8}$ & I & $\cdots$ & $\ldots$ & $\cdots$ & 4 & $\cdots$ & $\cdots$ & $\cdots$ & I 8 & I 33 \\
\hline 12. Cowley-Chislehamp & pton & & 21 & $\cdots$ & $\cdots$ & $\cdots$ & $\cdots$ & 5 & $\cdots$ & 4 & $\cdots$ & $\cdots$ & $\cdots$ & $\cdots$ & 30 \\
\hline 13. Wooton-Abingdon & & • & $5^{1}$ & $\cdots$ & 35 & 2 & $\cdots$ & 8 & $\cdots$ & $\cdots$ & I & $\cdots$ & $\cdots$ & 4 & 97 \\
\hline 14. Woodperry Corner & & & 37 & $\cdots$ & 28 & $\cdots$ & ... & $\cdots$ & $\cdots$ & $\cdots$ & 6 & $\cdots$ & * & 5 & 71 \\
\hline 15. Wheatley-Holton & & . & $5 \mathrm{I}$ & $\cdots$ & $3^{2}$ & 5 & $\cdots$ & $\cdots$ & $\cdots$ & $\cdots$ & $\cdots$ & $\cdots$ & $\cdots$ & ro & 88 \\
\hline $\begin{array}{l}\text { 16. Kingstone Coombes } \\
\text { I 7. Etchilhampton }\end{array}$ & & & $\begin{array}{l}41 \\
18\end{array}$ & $\begin{array}{l}\cdots \\
\cdots\end{array}$ & $\begin{aligned} I \\
30\end{aligned}$ & $\begin{array}{l}2 \\
. .\end{array}$ & $\cdots$ & $\begin{array}{l}\cdots \\
\cdots\end{array}$ & $\begin{array}{l}\cdots \\
\cdots\end{array}$ & $\begin{array}{l}\cdots \\
\cdots\end{array}$ & $\begin{array}{l}\cdots \\
\ldots\end{array}$ & $\begin{array}{l}\cdots \\
\ldots\end{array}$ & $\begin{array}{l}\cdots \\
\ldots\end{array}$ & $\begin{array}{r}24 \\
9\end{array}$ & $\begin{array}{l}44 \\
48\end{array}$ \\
\hline ı8. Kingston Bagpuize- & & & II & $\ldots$ & $I I$ & $I$ & & $I$ & & & & & & & \\
\hline Standlake & & & 11 & $\cdots$ & 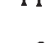 & 1 & $\cdots$ & 1 & $\cdots$ & $\cdots$ & $\cdots$ & $\cdots$ & $\cdots$ & 3 & 24 \\
\hline 19. Watlington Hill & & - & $\cdots$ & $\cdots$ & 6 & $\cdots$ & $\cdots$ & $\cdots$ & $\cdots$ & $\cdots$ & $\cdots$ & $\cdots$ & $\cdots$ & $\cdots$ & 6 \\
\hline 20. Forest Hill-Stanton & & • & 8 & $\cdots$ & I 3 & $\cdots$ & $\cdots$ & $\cdots$ & $\cdots$ & $\cdots$ & $\cdots$ & $\cdots$ & $\cdots$ & $\cdots$ & $2 \mathrm{I}$ \\
\hline Total & - & • & 949 & $\cdots$ & 889 & 27 & 4 & 33 & $4^{I}$ & 18 & II & $\cdots$ & 2 & 340 & 1972 \\
\hline Hedgerows and Rough $H$ & Terbas & & & & & & & & & & & & & & \\
\hline $\begin{array}{l}\text { 1. Cumnor } \\
\text { 2. Wootton Rivers }\end{array}$ & : & & $\begin{array}{l}43 \\
17\end{array}$ & $\ldots$ & $\begin{array}{c}7 \\
\ldots\end{array}$ & $\begin{array}{c}\mathrm{I} \\
\ldots\end{array}$ & $\begin{array}{c}\cdots \\
2\end{array}$ & $\dddot{m}_{2}$ & $\begin{array}{l}\cdots \\
\ldots\end{array}$ & 当 & $\begin{array}{c}\mathrm{I} \\
\ldots\end{array}$ & $\begin{array}{l}\ldots \\
\ldots\end{array}$ & * & $\begin{array}{l}6 \\
\mathrm{I}\end{array}$ & $\begin{array}{l}52 \\
22\end{array}$ \\
\hline 3. Marston-Elsfield & & & 22 & $\ldots$ & $\ldots$ & $\ldots$ & $\ldots$ & $\ldots$ & $\ldots$ & $\ldots$ & 4 & & * & 6 & 26 \\
\hline 4. Stowood Crossroads & & & 25 & 2 & 8 & I & ... & 2 & $\ldots$ & 2 & I & $\ldots$ & $\ldots$ & 6 & $4^{I}$ \\
\hline 5. Oare Hill A & & • & 133 & $\cdots$ & 14 & 65 & $\cdots$ & ... & $\cdots$ & $\cdots$ & $\cdots$ & $\cdots$ & * & 27 & 212 \\
\hline 6. Oare Hill B. & - & & 5 & $\cdots$ & $\cdots$ & $\cdots$ & $\cdots$ & $\cdots$ & $\cdots$ & $\cdots$ & $\cdots$ & $\cdots$ & $\cdots$ & $\begin{array}{l}\text { I } \\
\end{array}$ & 5 \\
\hline $\begin{array}{l}\text { 7. Derry Hill A } \\
\text { 8. Rockley, Berks }\end{array}$ & - & & 30 & $\cdots$ & 9 & 当 & $\cdots$ & 3 & $\begin{array}{l}\cdots \\
\ldots\end{array}$ & $\cdots$ & 2 & $\cdots$ & $\cdots$ & 8 & 44 \\
\hline O. KOCKIey, DetKS & & & 17 & 2 & 9 & & $\cdots$ & & & $\cdots$ & $\cdots$ & $\cdots$ & $\cdots$ & 3 & 33 \\
\hline 9. Wooton-Abingdon & & • & 136 & $2 \mathrm{I}$ & $5^{2}$ & 5 & $\cdots$ & 10 & $\cdots$ & ... & 5 & I & * & 14 & 230 \\
\hline Io. Swerford & & & $4^{6}$ & $\cdots$ & 12 & I & .. & .. & $\cdots$ & $\cdots$ & $\cdots$ & ... & & 26 & 59 \\
\hline II. Christmas Common & & & 7 & $\cdots$ & 38 & $\dddot{m}$ & $\cdots$ & $\cdots$ & $\cdots$ & $\cdots$ & 2 & $\cdots$ & $\dddot{*}$ & $\cdots$ & 47 \\
\hline 12. Fiddler's Hill & & $\cdot$ & I 74 & $\cdots$ & 39 & 16 & $\cdots$ & $\cdots$ & $\cdots$ & $\cdots$ & $\cdots$ & .. & ${ }^{*}$ & I & 229 \\
\hline 13. Springhill & - & & 13 & $\cdots$ & $\cdots$ & $\cdots$ & $\cdots$ & $\cdots$ & $\cdots$ & $\cdots$ & I & $\cdots$ & * & $\cdots$ & 14 \\
\hline $\begin{array}{l}\text { I4. Ashbury Hill } \\
\text { I5. Derry Hill B . }\end{array}$ & • & & $\begin{array}{l}4 \\
6\end{array}$ & $\begin{array}{l}\cdots \\
\cdots\end{array}$ & $\dddot{7}$ & $\begin{array}{l}3 \\
\ldots\end{array}$ & $\begin{array}{l}\cdots \\
\ldots\end{array}$ & $\ddot{12}$ & $\begin{array}{l}\cdots \\
\ldots\end{array}$ & $\begin{array}{l}\cdots \\
\cdots\end{array}$ & $\begin{array}{l}\text { I } 2 \\
\ldots\end{array}$ & $\begin{array}{c}9 \\
\ldots\end{array}$ & ... & $\begin{array}{l}1 \\
2\end{array}$ & $\begin{array}{l}28 \\
25\end{array}$ \\
\hline Total & . & & 678 & 25 & 195 & 93 & 2 & 33 & $\ldots$ & 3 & 28 & 10 & 8 & 102 & 1067 \\
\hline
\end{tabular}


random samples of $\mathrm{G}$. hortensis.

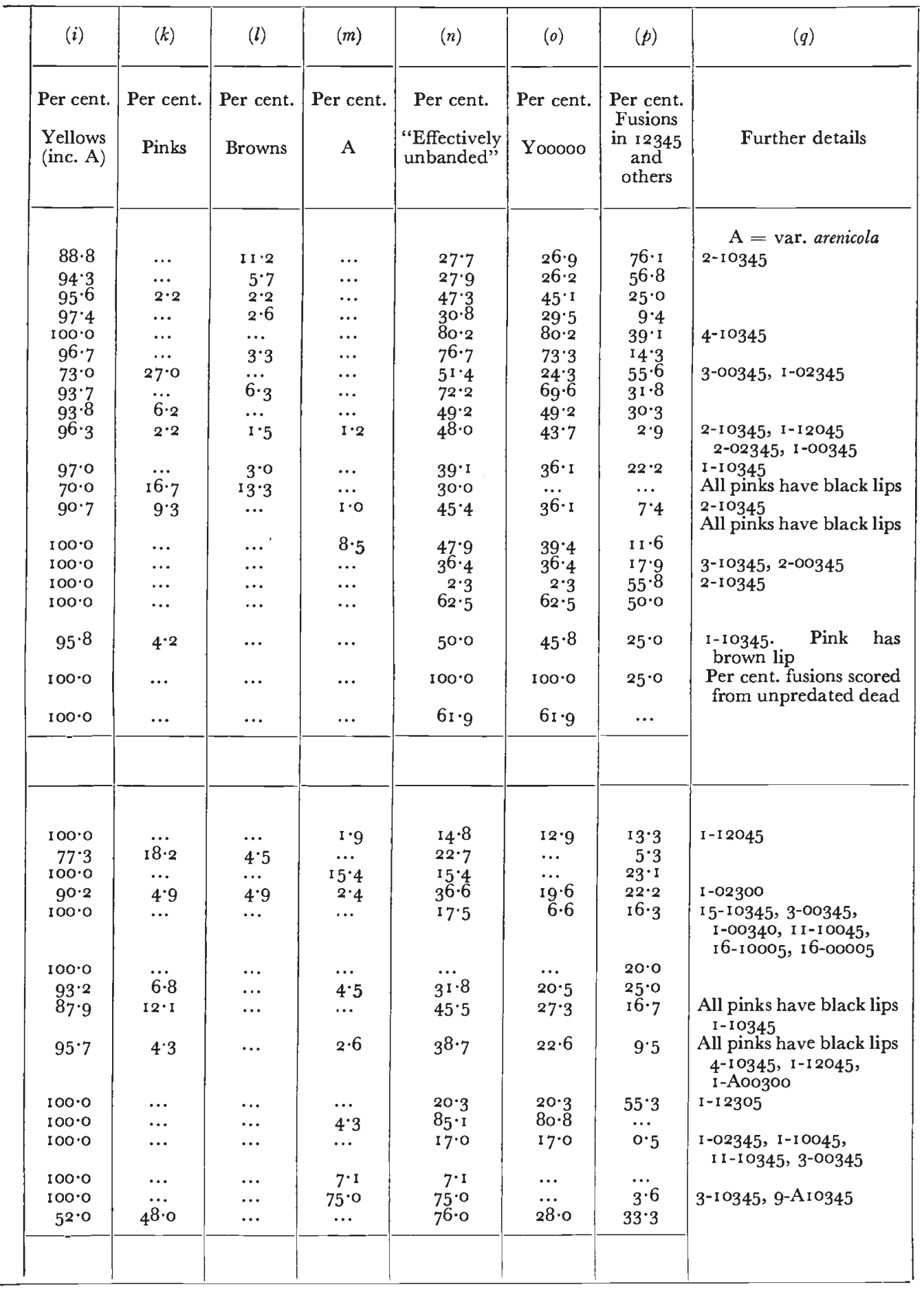


TABLE 2-The composition of

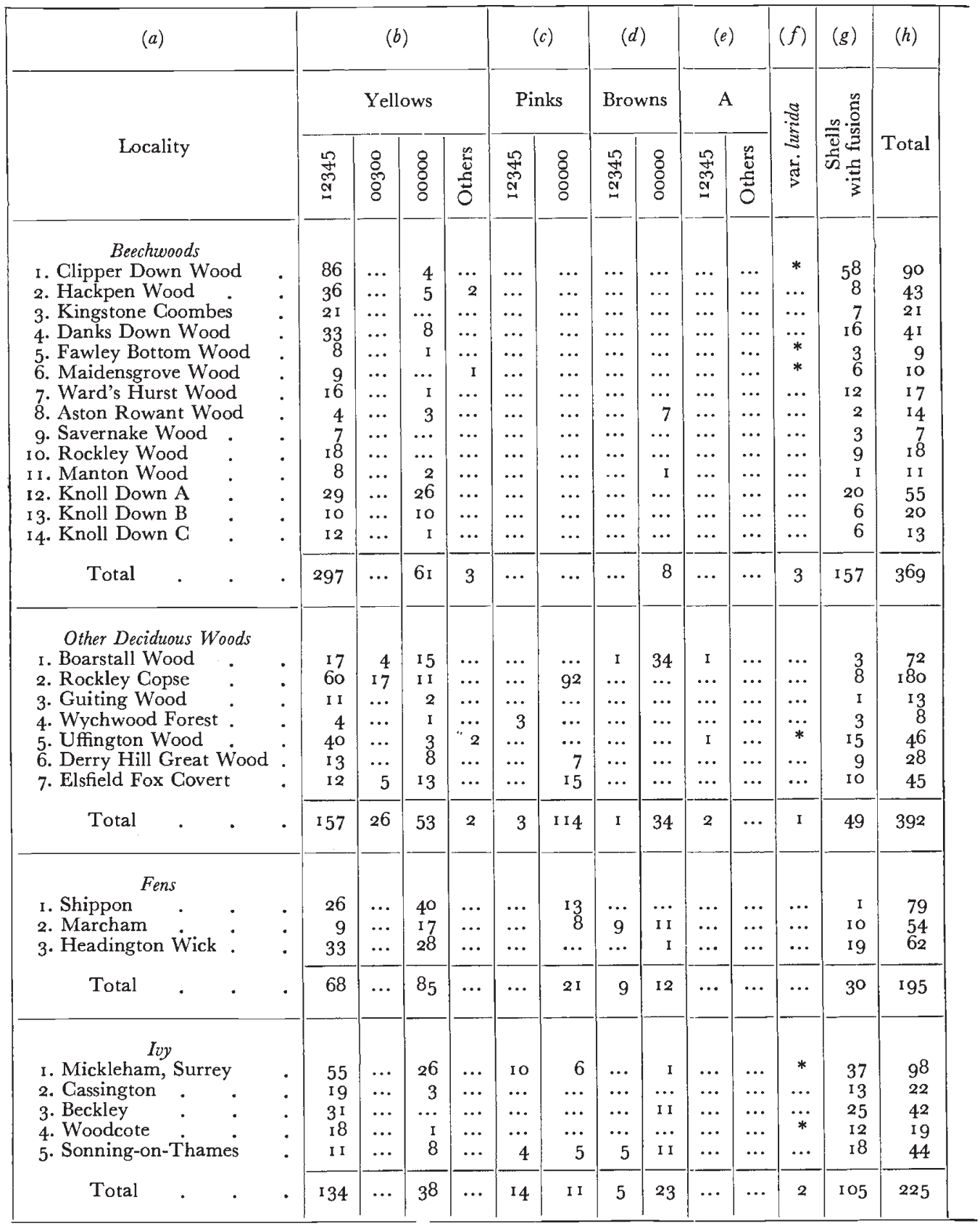


random samples of $\mathrm{C}$. hortensis (continued).

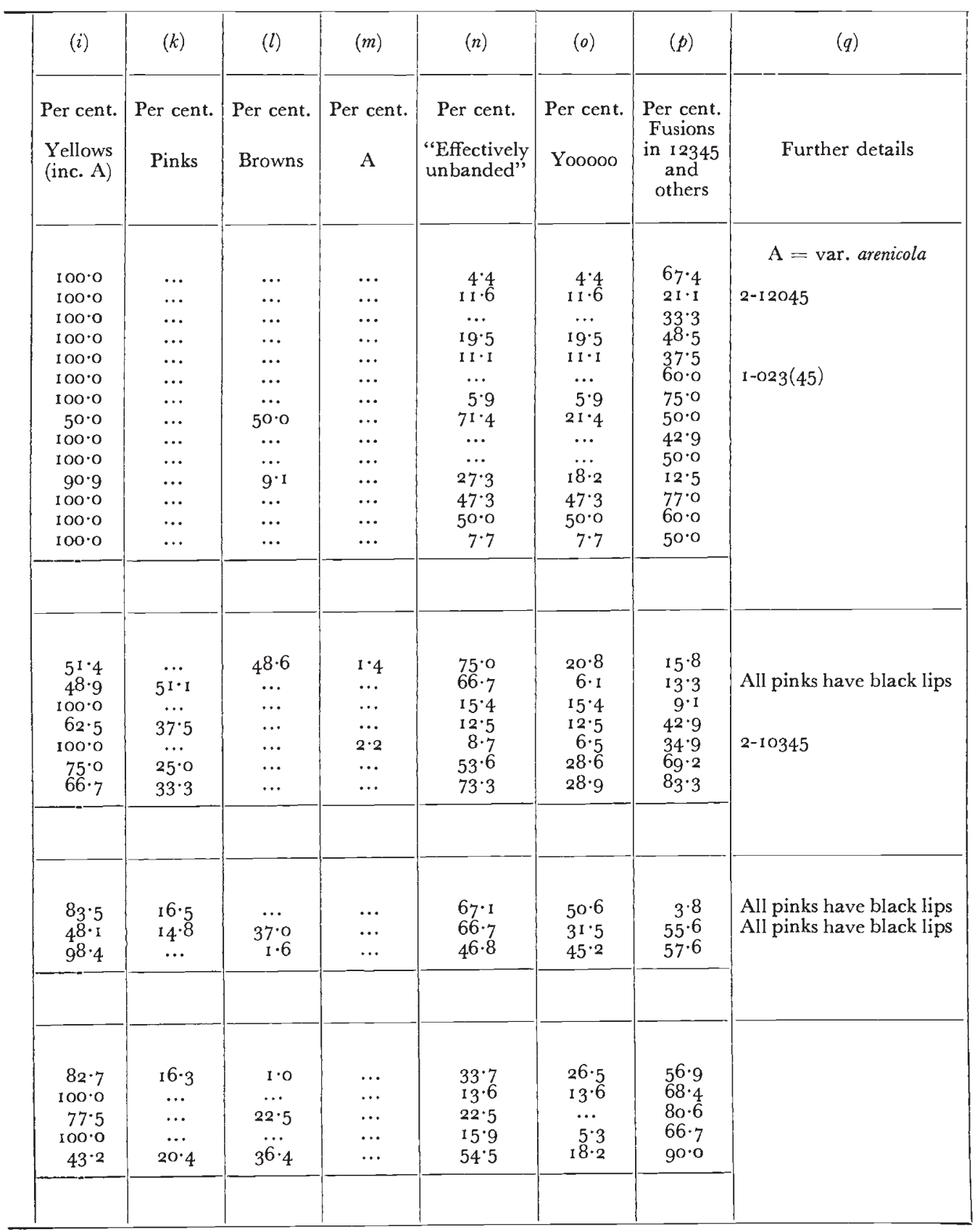


selection sufficient to account for the observed differences in the distribution of phenotypes between populations would not show itself within them unless the samples of both live and predated adults were very large indeed.

If the data given in tables $I$ and 2 are compared with Cain and Sheppard's (r954) results for Cepaea nemoralis from the same region, it is seen that the two species differ profoundly in the distribution of their

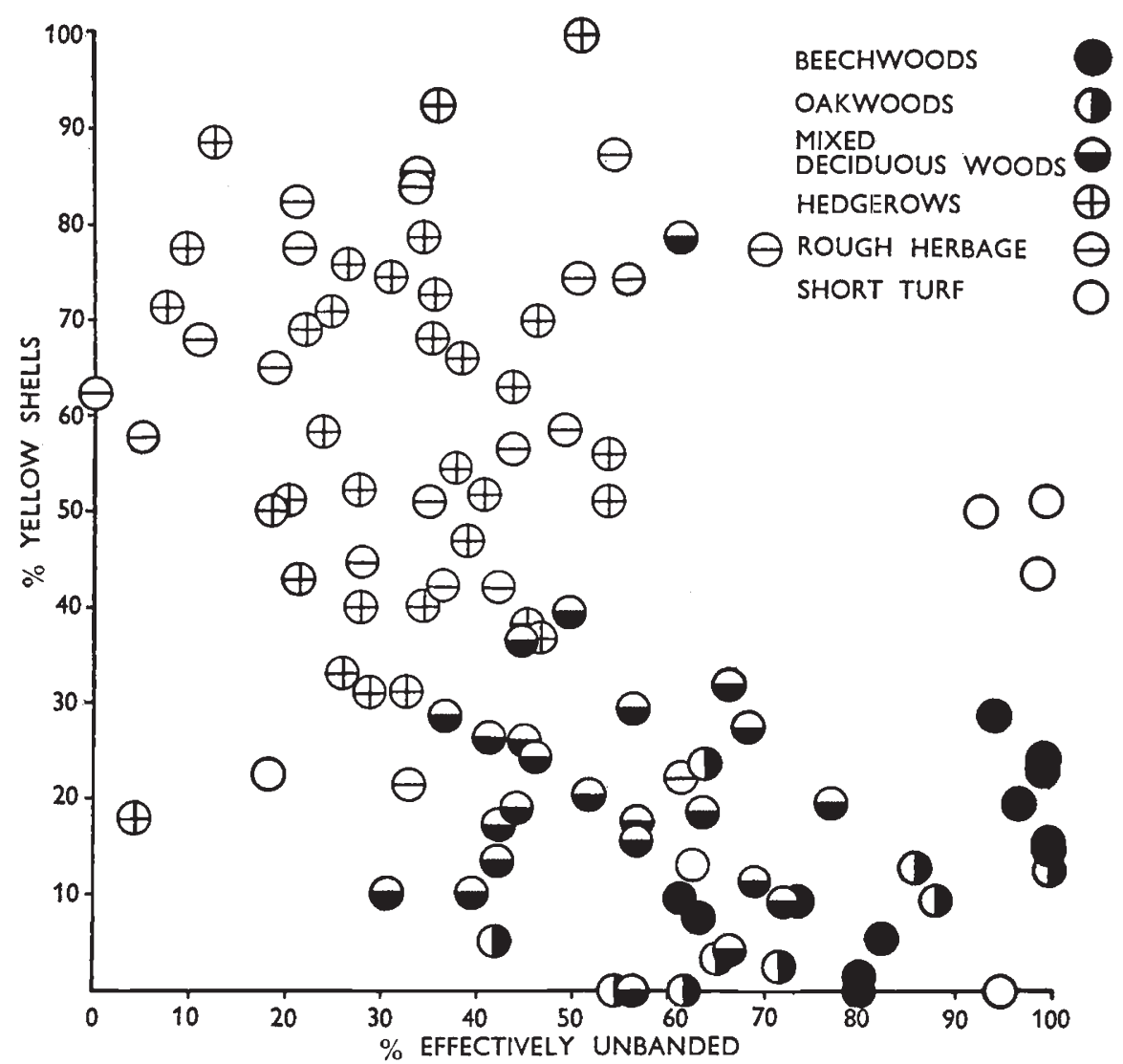

Fic. 2.-C. nemoralis. A scatter-diagram showing the relation between percentage of yellow shells, percentage of "effectively unbanded" shells, and the nature of the habitat (after Cain and Sheppard, 1954).

phenotypes. In hortensis there is far less variation in the proportion of yellow shells. In nearly every case they form the greater part of the population (columns $(b)$ and (i)). Albino shells (var. arenicola) are more common than in nemoralis (columns $(e)$ and $(m)$ ), as are palebanded forms (column $(f)$ ) and banded browns (column $(d)$ ). Banded pinks, on the other hand, are much rarer.

The tables show also that the distribution of phenotypes is not random with respect to habitat. Grasslands, for instance, tend to have a higher proportion of unbanded shells than beechwoods (see column 
$(n))$. The converse is true in C. nemoralis. Figs. 2 and 3 show this clearly.

Fig. 2 is the scatter-diagram given by Cain and Sheppard (1954). Each spot represents one colony of nemoralis. The position of a spot along the vertical axis is determined by the percentage of yellow

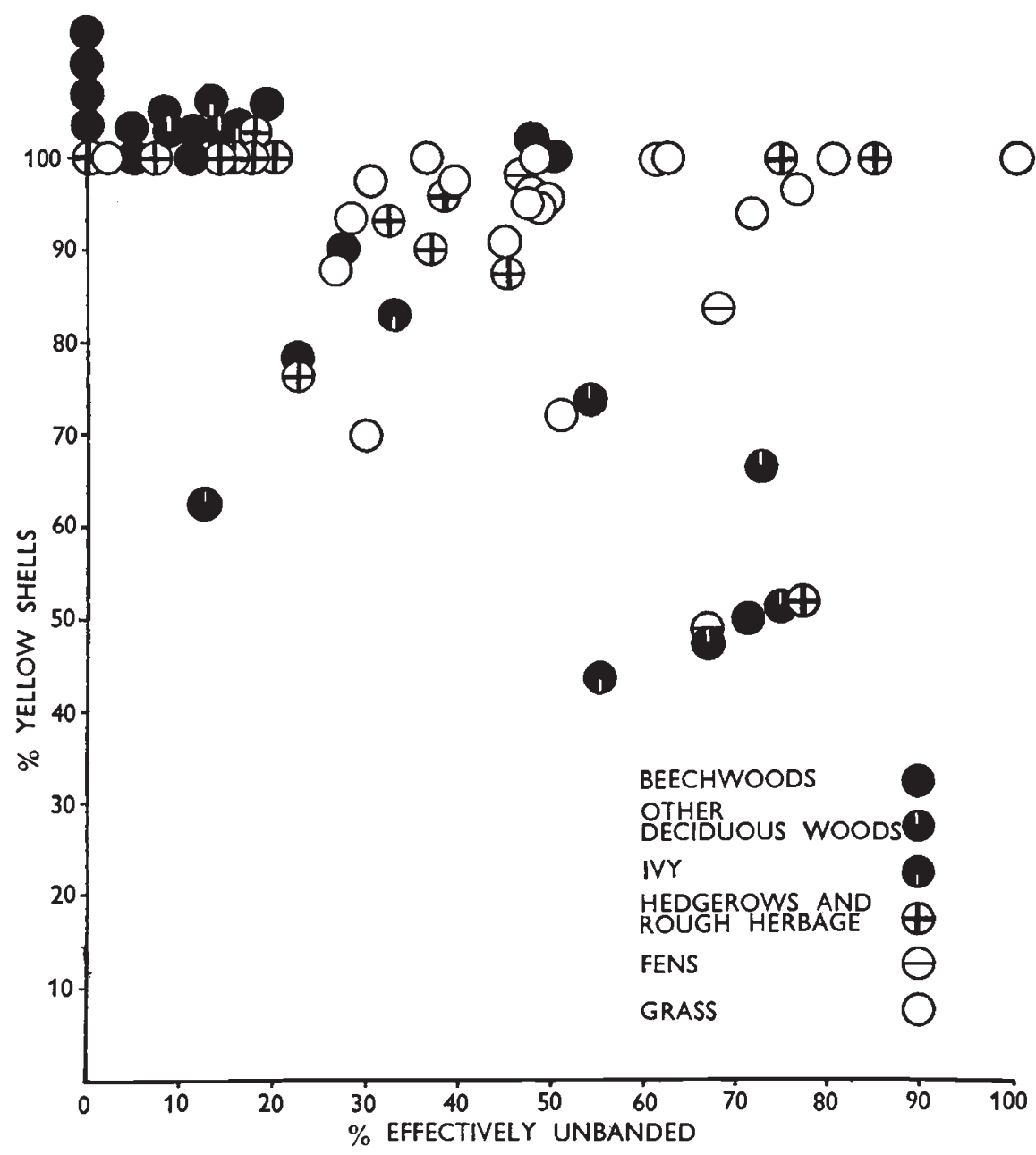

Fig. 3.-C. hortensis. A scatter-diagram similar to fig. 2, showing the different distribution of phenotypes in this species.

shells in the colony. Along the horizontal axis its position is determined by the percentage of "effectively unbanded" shells (i.e. those shells that have the top two bands missing, including 00300, 00345, o0045, ooooo, etc.). On the diagram, colonies from each habitat class tend to be grouped together. The beechwoods lie at the lower right-hand corner, having a low proportion of yellow and a high proportion of unbanded shells. The more open habitats, such as hedgerows and rough herbage, tend towards the left-hand corner. It 
must be noted that Cain and Sheppard (1954) class hedgerows and rough herbage as separate groups, but include grasslands in the latter category.

Fig. 3 is a similar diagram, drawn for my collections of $C$. hortensis. Although there is some separation between habitat classes, the grouping

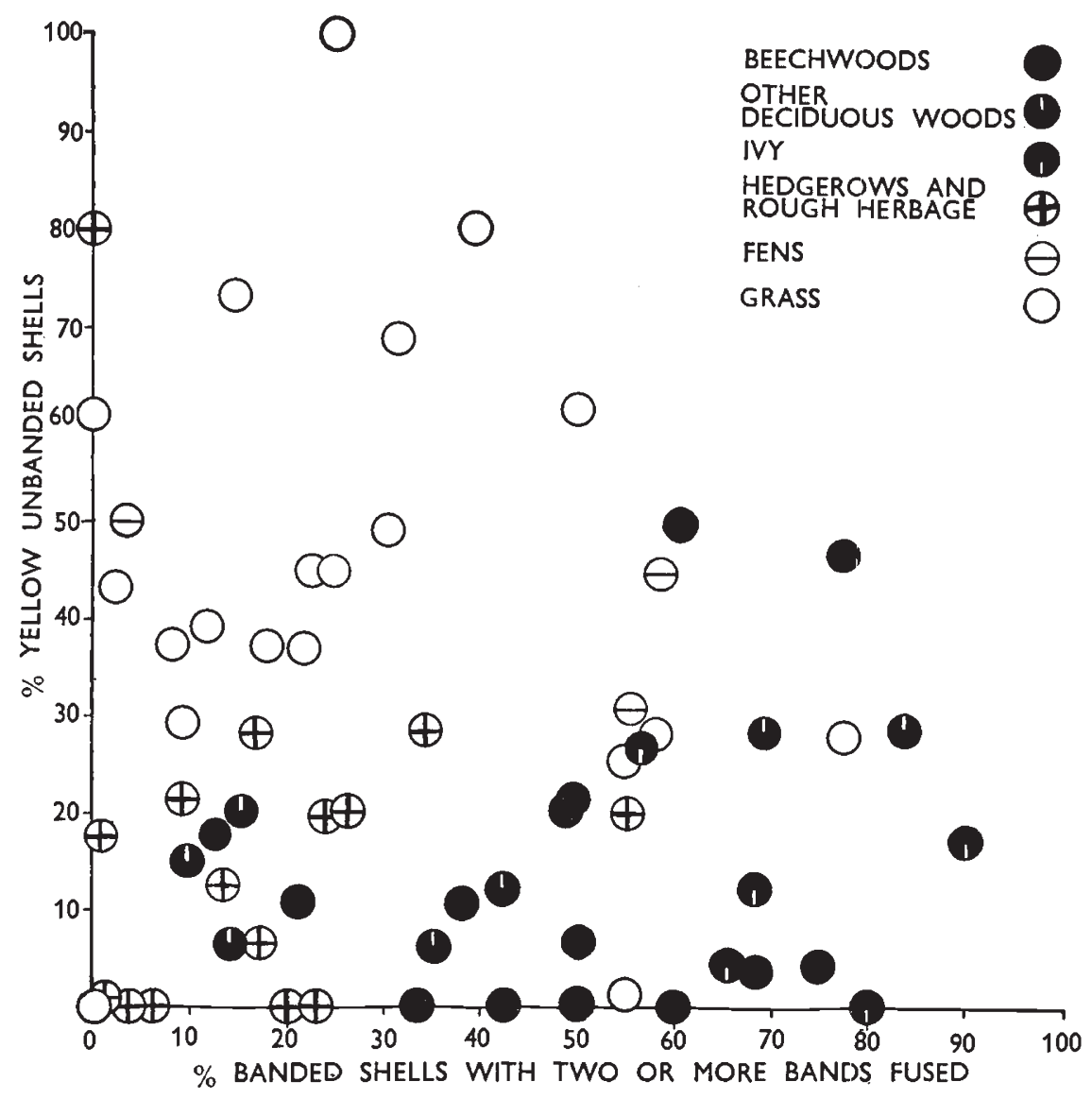

FIG. 4.-C. hortensis. A scatter-diagram showing the relation between percentage of yellow unbanded shells, percentage of banded shells with fused bands (see text) and the nature of the habitat.

here is much less distinct. Furthermore, the beechwoods tend to fall on the left-hand side, and the grasslands on the right.

Tables I and 2 show that the greater part of the variation of $C$. hortensis is within the yellow colour class. Fig. 4, another scatter-diagram, makes allowance for this. Along the vertical axis are plotted the percentages of yellow unbanded shells (tables I and 2, column (o)). The horizontal axis gives the proportions of banded shells that have two or more bands fused together (tables I and 2, column $(p)$ ). These proportions are expressed as percentages of the numbers of shells that could have two or more bands fused (i.e. shells with bands next to 
each other-including such forms at I 2345, I 0045, I 2045, 00345, etc., but excluding ooooo, oo300, I 0005, I0305, etc.).

Fig. 4 shows a clear separation into colour classes. The woodlands, which have few yellow unbanded shells and a high proportion of fusions, are almost completely distinct from the grasslands. The hedgerows and rough herbage, as might be expected, take up a more or less intermediate position. The samples taken under ivy, the darkest habitat, have high percentages of fusions.

The three figures show clearly that hortensis populations respond to the influence of the habitat, but that the response is very different from that of nemoralis.

\section{RELIABILITY OF RESULTS}

The results obtained might be affected by several possible errors:

(i) There are, no doubt, random errors of sampling. They would not, of course, give the systematic differences that have been observed between habitat classes. The significance of these differences can easily be demonstrated by non-parametric methods. The samples are arranged in order according to the percentage of shells displaying a particular character, and the distribution of habitat classes about the median percentage is tested by $\chi^{2}$, the null hypothesis being that, in each habitat, there should be equal numbers of samples falling on either side of the median. For the two characters used in fig. 4 it is found that beechwoods, other deciduous woods, and ivy do not differ significantly from one another and that therefore they can be grouped together for comparison with the other two major classes (hedgerows, rough herbage and grasslands). The distributions of both the percentage of yellow unbanded and the percentage of fusions give $3 \times 2$ tables with probabilities that are less than one in a thousand. More refined statistical treatments give even lower values.

(ii) I may have collected too high a proportion of shells that appear conspicuous to the eye. There is no doubt, however, that yellow unbanded shells are more obvious against the dark background of woodlands than are pink, brown, or banded forms-and that shells with their bands fused together are more difficult to see in such situations than are banded shells without fusions. Furthermore, in uniform green grass or herbage the yellow unbanded forms are less obvious than the banded ones, particularly less so than shells with fused bands. Thus any errors of selection by the collector could only tend to obscure the observed differences between habitat classes. This applies also to samples of broken shells collected by thrushes.

(iii) Schnetter and Sedlmair (I 953) and Sedlmair (1956) claim to have detected differences in behaviour under experimental conditions between various phenotypes of Cepaea. Banded forms of hortensis, for instance, were significantly more active than unbanded when the humidity was high. In dry conditions the activity of the unbanded 


\section{B. CLARKE}

TABLE 3

Comparison of samples taken from the same places at different times (see text).

\begin{tabular}{|c|c|c|c|c|c|c|c|c|}
\hline Locality & $\mathrm{Y}$ & $\mathrm{P}$ & B & I 2345 & F & Total & Date & Comments \\
\hline Uffington Wood & $\begin{array}{l}46 \\
21\end{array}$ & $\begin{array}{l}0 \\
0\end{array}$ & $\begin{array}{l}0 \\
0\end{array}$ & $\begin{array}{l}43 \\
20\end{array}$ & $\begin{array}{r}\text { I } 5 \\
6\end{array}$ & $\begin{array}{l}46 \\
2 \mathrm{I}\end{array}$ & $\begin{array}{r}12.6 .57 \\
5.6 .5^{8}\end{array}$ & $\begin{array}{l}\text { L. } \\
\text { L. }\end{array}$ \\
\hline Boarstall Wood & $\begin{array}{l}22 \\
15 \\
\end{array}$ & $\begin{array}{l}0 \\
0\end{array}$ & $\begin{array}{l}\text { I9 } \\
\text { I6 }\end{array}$ & $\begin{array}{r}8 \\
\text { I I }\end{array}$ & $\begin{array}{l}0 \\
3\end{array}$ & $\begin{array}{l}4 \mathrm{I} \\
3 \mathrm{I}\end{array}$ & $\begin{array}{c}8.6 .57 \\
195 \mathrm{I} \\
\end{array}$ & $\begin{array}{l}\text { L. } \\
\text { T., Cain \& Sheppard }\end{array}$ \\
\hline Clipper Down Wood & $\begin{array}{l}63 \\
27 \\
\end{array}$ & $\begin{array}{l} \\
\\
0\end{array}$ & $\begin{array}{l}0 \\
0\end{array}$ & $\begin{array}{l}61 \\
25 \\
\end{array}$ & $\begin{array}{l}42 \\
16\end{array}$ & $\begin{array}{l}63 \\
27 \\
\end{array}$ & $\begin{array}{l}10.6 .57 \\
10.6 .57 \\
\end{array}$ & $\begin{array}{ll}\mathrm{L} . \\
\mathrm{T} .\end{array}$ \\
\hline Kingstone Coombes Wood & $\begin{array}{l}\text { I9 } \\
2 \mathrm{I} \\
\end{array}$ & $\begin{array}{l}0 \\
0 \\
\end{array}$ & $\begin{array}{l}0 \\
0 \\
0\end{array}$ & $\begin{array}{l}18 \\
20 \\
\end{array}$ & $\begin{array}{l}5 \\
7 \\
\end{array}$ & $\begin{array}{l}19 \\
2 \mathrm{I} \\
\end{array}$ & $\begin{array}{c}\text { I } 95 \text { I } \\
29 \cdot 5 \cdot 57 \\
\end{array}$ & $\begin{array}{l}\text { T., Cain \& Sheppard } \\
\text { T. }\end{array}$ \\
\hline Rockley Copse & $\begin{array}{l}19 \\
63 \\
\end{array}$ & $\begin{array}{l}26 \\
61 \\
\end{array}$ & $\begin{array}{l}0 \\
0\end{array}$ & $\begin{array}{l}\text { I3 } \\
43 \\
\end{array}$ & $\begin{array}{l}2 \\
5 \\
\end{array}$ & $\begin{array}{r}45 \\
124 \\
\end{array}$ & $\begin{array}{c}\text { I } 952 \\
\text { I } 4.6 .57 \\
\end{array}$ & $\begin{array}{l}\text { T., Cain \& Sheppard } \\
\text { T. }\end{array}$ \\
\hline Shippon Fen . & $\begin{array}{r}45 \\
53 \mathrm{I} \\
\end{array}$ & $\begin{array}{r}9 \\
84 \\
\end{array}$ & $\begin{array}{l}0 \\
0 \\
\end{array}$ & $\begin{array}{r}17 \\
259 \\
\end{array}$ & $\begin{array}{r}1 \\
16 \\
\end{array}$ & $\begin{array}{r}54 \\
615 \\
\end{array}$ & $\begin{array}{l}22 \cdot 3 \cdot 57 \\
21 \cdot 3 \cdot 59 \\
\end{array}$ & $\begin{array}{l}\text { L. } \\
\text { T. }\end{array}$ \\
\hline Wooton-Abingdon Road . & $\begin{array}{l}\text { I13 } \\
107 \\
\end{array}$ & $\begin{array}{l}6 \\
4 \\
\end{array}$ & $\begin{array}{l}0 \\
0 \\
\end{array}$ & $\begin{array}{l}73 \\
73\end{array}$ & $\begin{array}{l}5 \\
7 \\
\end{array}$ & $\begin{array}{ll}\text { I I } 9 \\
\text { I I I }\end{array}$ & $\begin{array}{r}30.4 \cdot 57 \\
4 \cdot 5 \cdot 57 \\
\end{array}$ & $\begin{array}{l}\text { L. } \\
\text { L. }\end{array}$ \\
\hline Oare Hill & $\begin{array}{r}19 I \\
2 I \\
\end{array}$ & o & $\begin{array}{l}0 \\
0\end{array}$ & $\begin{array}{r}178 \\
20 \\
\end{array}$ & $\begin{array}{r}26 \\
1\end{array}$ & $\begin{array}{r}191 \\
21 \\
\end{array}$ & $\begin{array}{l}1950 \\
6.6 .57\end{array}$ & $\begin{array}{l}\text { L., Cain \& Sheppard } \\
\text { L. }\end{array}$ \\
\hline Shepherd's Rest & $\begin{array}{r}227 \\
19 \\
\end{array}$ & $\begin{array}{l} \\
0 \\
0\end{array}$ & $\begin{array}{l}0 \\
0\end{array}$ & $\begin{array}{r}\text { I93 } \\
\text { I9 } \\
\end{array}$ & $\begin{array}{l}7 \\
0 \\
\end{array}$ & $\begin{array}{r}227 \\
19 \\
\end{array}$ & $\begin{array}{c}\text { I } 957 \\
\text { I } 4.4 \cdot 58 \\
\end{array}$ & $\begin{array}{l}\text { L., Sheppard } \\
\text { L. }\end{array}$ \\
\hline Wheatley Bridge & $\begin{array}{l}63 \\
66 \\
\end{array}$ & $\begin{array}{l}0 \\
0 \\
\end{array}$ & $\begin{array}{l}2 \\
2 \\
\end{array}$ & $\begin{array}{l}39 \\
42 \\
\end{array}$ & $\begin{array}{r}8 \\
10\end{array}$ & $\begin{array}{l}65 \\
68 \\
\end{array}$ & $\begin{array}{l}10.4 \cdot 57 \\
10.4 .57 \\
\end{array}$ & $\begin{array}{l}\text { L. } \\
\text { M. }\end{array}$ \\
\hline Dragons Hill . & $\begin{array}{r}169 \\
54 \\
62 \\
24 \\
34 \\
43 \\
36 \\
\end{array}$ & $\begin{array}{l}0 \\
0 \\
0 \\
0 \\
0 \\
0 \\
0\end{array}$ & $\begin{array}{l}0 \\
0 \\
0 \\
0 \\
0 \\
0 \\
0\end{array}$ & $\begin{array}{r}3 \mathrm{I} \\
9 \\
\mathrm{I} 4 \\
6 \\
6 \\
6 \\
9 \\
9\end{array}$ & $\begin{array}{r}\text { I I } \\
5 \\
8 \\
0 \\
4 \\
4 \\
4 \\
\end{array}$ & $\begin{array}{r}69 \\
54 \\
62 \\
24 \\
34 \\
43 \\
36 \\
\end{array}$ & $\begin{array}{l}\text { I } 6.9 \cdot 56 \\
\text { I } 6.4 \cdot 57 \\
\text { I } 6.4 .57 \\
\text { I } 2.6 .57 \\
\text { I } 6.4 \cdot 58 \\
\text { I } 5 \cdot 4 \cdot 59 \\
\text { I } 5 \cdot 4.59\end{array}$ & $\begin{array}{l}\text { L. } \\
\text { L. } \\
\text { M. \& T. } \\
\text { L. } \\
\text { L. } \\
\text { L. } \\
\text { M. \& T. }\end{array}$ \\
\hline Silbury Hill, G & $\begin{array}{r}87 \\
260 \\
62 \\
224 \\
143 \\
\end{array}$ & $\begin{array}{l}2 \\
\mathrm{I} \\
\mathrm{I} \\
\mathrm{O} \\
\mathrm{O}\end{array}$ & $\begin{array}{r}2 \\
10 \\
4 \\
2 \\
5\end{array}$ & $\begin{array}{r}4^{8} \\
\text { I } 51 \\
3^{8} \\
\text { I } 6 \\
77 \\
7\end{array}$ & $\begin{array}{r}9 \\
69 \\
16 \\
37 \\
31 \\
\end{array}$ & $\begin{array}{r}91 \\
271 \\
67 \\
226 \\
148 \\
\end{array}$ & $\begin{array}{r}6.6 .57 \\
17 \cdot 6.5^{8} \\
2.9 \cdot 5^{8} \\
24 \cdot 10.5^{8} \\
20.4 \cdot 59 \\
\end{array}$ & $\begin{array}{l}\text { L., V.S. } \\
\text { L., V.C. } \\
\text { L., Reynolds, V.S. } \\
\text { L., Paterson \& Murray } \\
\text { ·L., V.S. }\end{array}$ \\
\hline Silbury Hill, 8 & $\begin{array}{l}72 \\
17 \\
\end{array}$ & $\begin{array}{l}\mathrm{o} \\
\mathrm{o} \\
\end{array}$ & $\begin{array}{r}10 \\
0 \\
\end{array}$ & $\begin{array}{l}59 \\
12 \\
\end{array}$ & $\begin{array}{r}43 \\
9 \\
\end{array}$ & $\begin{array}{l}82 \\
17\end{array}$ & $\begin{array}{l}\text { I } 7 \cdot 7 \cdot 57 \\
\text { I } 4.9 \cdot 5^{8} \\
\end{array}$ & $\begin{array}{l}\text { L. } \\
\text { L. }\end{array}$ \\
\hline White Horse Hill, I & $\begin{array}{l}33 \\
52 \\
\end{array}$ & $\begin{array}{l}\mathrm{o} \\
\mathrm{o}\end{array}$ & $\begin{array}{l}0 \\
0\end{array}$ & $\begin{array}{l}3 \mathrm{I} \\
52\end{array}$ & $\begin{array}{r}9 \\
12 \\
\end{array}$ & $\begin{array}{l}33 \\
52 \\
\end{array}$ & $\begin{array}{l}\text { I } 6.4 .5^{8} \\
\text { I } 5.4 .59 \\
\end{array}$ & $\begin{array}{l}\text { L. } \\
\text { L. }\end{array}$ \\
\hline Little Hinton . & $\begin{array}{l}33 \\
28 \\
\end{array}$ & $\begin{array}{l}0 \\
0\end{array}$ & $\begin{array}{l}0 \\
0\end{array}$ & $\begin{array}{l}25 \\
24 \\
\end{array}$ & $\begin{array}{l}4 \\
4 \\
\end{array}$ & $\begin{array}{l}33 \\
28 \\
\end{array}$ & $\begin{array}{l}\text { I } 9.4 .59 \\
\text { I } 9.4 .59 \\
\end{array}$ & $\begin{array}{l}\text { T. (new shells) } \\
\text { T. (old shells) }\end{array}$ \\
\hline Fyfield Roadbank, I & $\begin{array}{r}\text { I } 3 \\
84 \\
44 \\
58 \\
32 \\
57 \\
80 \\
\end{array}$ & $\begin{array}{l}0 \\
0 \\
0 \\
0 \\
0 \\
0 \\
0\end{array}$ & $\begin{array}{l}0 \\
0 \\
0 \\
0 \\
0 \\
0 \\
\mathrm{I}\end{array}$ & $\begin{array}{l}52 \\
39 \\
27 \\
34 \\
18 \\
27 \\
31\end{array}$ & $\begin{array}{r}\text { I I } \\
7 \\
5 \\
8 \\
4 \\
8 \\
\text { I } 4 \\
\end{array}$ & $\begin{array}{r}\text { I } 3 \\
84 \\
44 \\
58 \\
32 \\
57 \\
81 \\
\end{array}$ & $\begin{array}{r}6.5^{8} \\
6.5^{8} \\
6.5^{8} \\
6.5^{8} \\
20.4 \cdot 59 \\
20.4 .59 \\
20.4 .59 \\
\end{array}$ & $\begin{array}{l}\text { L., Armstrong } \\
\text { L., Armstrong } \\
\text { L., Armstrong } \\
\text { L., Armstrong } \\
\text { L. On ground } \\
\text { L. Climbing } \\
\text { L. }\end{array}$ \\
\hline Fyfield Roadbank, 2 & $\begin{array}{l}4 \mathrm{I} \\
39 \\
49 \\
57\end{array}$ & $\begin{array}{l}0 \\
0 \\
0 \\
0\end{array}$ & $\begin{array}{l}0 \\
0 \\
0 \\
0 \\
\end{array}$ & $\begin{array}{l}20 \\
17 \\
26 \\
27 \\
\end{array}$ & $\begin{array}{l}2 \\
3 \\
8 \\
6 \\
\end{array}$ & $\begin{array}{l}4 \mathrm{I} \\
39 \\
49 \\
57 \\
\end{array}$ & $\begin{array}{r}6.5^{8} \\
6.5^{8} \\
6.5^{8} \\
6.5^{8} \\
\end{array}$ & $\begin{array}{l}\text { L., Armstrong } \\
\text { L., Armstrong } \\
\text { L., Armstrong } \\
\text { L., Armstrong }\end{array}$ \\
\hline Fyfield Roadbank, 3 & $\begin{array}{l}70 \\
51 \\
21 \\
5^{8}\end{array}$ & $\begin{array}{l}0 \\
0 \\
0 \\
0\end{array}$ & $\begin{array}{r}\text { IO } \\
4 \\
3 \\
5\end{array}$ & $\begin{array}{r}44 \\
34 \\
6 \\
34\end{array}$ & $\begin{array}{r}26 \\
19 \\
3 \\
20\end{array}$ & $\begin{array}{l}80 \\
55 \\
24 \\
63\end{array}$ & $\begin{array}{r}\mathrm{I} .7 \cdot 57 \\
\mathrm{I} \cdot 7 \cdot 57 \\
24 \cdot 9 \cdot 57 \\
24 \cdot 9 \cdot 57\end{array}$ & $\begin{array}{l}\text { L. } \\
\text { T. } \\
\text { L. } \\
\text { T. }\end{array}$ \\
\hline
\end{tabular}

$\mathrm{L}=$ Live, $\mathrm{T}=$ Thrush predated, $\mathrm{M}=$ Mammal predated, V.S. = Vegetation standing, V.C. $=$ Vegetation cut (scythed). Thanks are due to Drs A. J. Cain, P. M. Sheppard and H. Paterson, and to Messrs A. Armstrong, J. Murray and K. Reynolds for allowing me to use their collections in this table. 
variety seemed to be greater, although in this case the difference was not statistically significant. Such experiments do not necessarily reflect what happens in natural populations, but they do show that environmental influence could introduce systematic errors into the samples. I have searched for effects of this sort, comparing collections taken from the same colony at various times, under various weather conditions. Table 3 summarises the results of these comparisons. I have included a number of samples that were collected after tables $\mathrm{I}$ and 2 had been drawn up. Full details of their composition will be recorded elsewhere.

In two localities (Silbury Hill C, and Fyfield Roadbank 3) there were apparent significant heterogeneities between successive samples, but an overall summation of $\chi^{2}$ (table 4 ) shows that this extent of

TABLE 4

Sums of $\chi^{2}$ comparing samples taken from the same colonies at different times-calculated from data of Table 3 .

\begin{tabular}{|lr|c|c|c|}
\hline & & Banding & Fusions & Colour \\
\hline Total $\chi^{2} \cdot$ & $\cdot$ & 29.31 & 33.30 & 12.58 \\
Degrees of freedom & $\cdot$ & 35 & 35 & 13 \\
Probability . &. & $>0.5$ & $>0.5$ & $>0.25$ \\
\hline
\end{tabular}

heterogeneity does not in fact exceed chance expectation. In none of the three classes (banding, fusions and colour) does the overall probability fall below $0 \cdot 25$.

I have also compared, in the field, samples taken from the stems and leaves of tall herbage with collections taken from the ground beneath them. As these comparisons were made on the spot, no figures are available, but in fifteen tests no significant differences were observed. It seems that differential behaviour does not significantly and directly alter the composition of samples, although it might well affect the selective advantages of varieties in a population.

We must conclude that the observed grouping of samples from similar habitats represents a genuine influence of the environment upon the composition of hortensis populations. This influence could be the result either of direct action by environment upon the phenotype of individual snails, or of natural selection acting upon genetically determined differences-or of both.

\section{GENETICS}

Many of the obvious colour and banding varieties of Cepaea are known to be genetically determined. C. hortensis has been bred by Lang (1904, 1912) and C. nemoralis by Lang (rgo8, 1911, 1912), Lamotte (1951, 1954) and Cain and Sheppard (1957). In hortensis, as in nemoralis, 
absence of banding is dominant to its presence, and pink is dominant to yellow (Lang, I 904). The inheritance of brown colour in hortensis is not known although, by analogy with nemoralis, brown may be expected to dominate pink and yellow. Lang's results suggest that band-fusions may be inherited. Boettger (1950) states that the different combinations of fused bands form an allelic series, but unfortunately he does not provide the necessary data. Forms with thin, interrupted bands are reported to be dominant to the more common thick-banded varieties (Lang, i912). Lang gives no information, however, about the inheritance of the unpigmented or partially pigmented conditionsalthough he has shown the former to be recessive in nemoralis (IgII). Phenocopies, as far as I know, have not been reported by reliable observers.

\section{NATURAL SELECTION}

Among populations of organisms, spatial or temporal differences in the proportions of genetically determined varieties can be due either to random or to directed processes (see, for instance, Wright, 1955). While " random drift" could, no doubt, occur within populations of hortensis, the systematic differences between habitat classes indicate the action of natural selection.

Sheppard (195I) has demonstrated the selection of colour varieties in two populations of $C$. nemoralis. He showed that the percentage of yellow snails killed by thrushes decreased from the middle of April until the middle of May. He gave evidence that this was the result neither of changes of feeding grounds by the thrushes, nor of variations in the populations from which they were collecting. The most obvious explanation was that the thrushes could see the yellow snails less easily as the background became greener.

Goodhart (1958b) reports similar seasonal differences in the proportions of pink and yellow hortensis collected by thrushes. His data cannot be considered as conclusive evidence of selection, for the following reasons:

(a) The population from which the birds were collecting was not sampled.

(b) The habitat was heterogeneous, and Goodhart did not exclude the possibility of seasonal changes of feeding ground.

(c) He compared the proportions of varieties found around " thrush stones" during five successive summers with those collected during the intervening winters. The proportion of pink shells in the two groups appeared to be significantly different $(\mathrm{p}<\mathrm{o} \cdot \mathrm{O} \mathrm{I})$. The final summer, however, showed a significantly higher proportion of pinks than the other summers $(\mathrm{p}<\mathrm{o} \cdot \mathrm{or})$, and ought not to have been included with them. When it is excluded, the difference between summers and winters is no longer significant $(\mathrm{p}>0 \cdot 05)$.

I have criticised Goodhart's work because the hypothesis of visual selection, if it is to be accepted, must be based upon unequivocal 
results. Nevertheless, for the reasons given below, it seems very likely that thrushes do, in fact, tend to select the most obvious varieties of hortensis, and to overlook those that resemble the background. Shells of this species are found on thrush stones as commonly as are those of nemoralis. Both species have similar colour and banding patterns. Since selective predation has been demonstrated in nemoralis, it is reasonable to expect the same in hortensis.

Predation by thrushes is not, of course, the only possible form of selection. Many other birds eat snails, and they may act in a similar way. Small mammals also prey upon Cepaea, and Cain (1953) has suggested that, since they are colour-blind, selection may depend on tone rather than colour. Boettger (I954) and Sedlmair (I956) have reported differences in survival between various phenotypes of hortensis and nemoralis under adverse conditions. Komai and Emura (1955) have discovered comparable differences in Bradybaena similaris.

Polymorphism in Cepaea has been in existence since Neolithic times (Diver, I 929) and probably for much longer. The presence of similar colour and banding varieties, not only in all the species of Cepaea, but also in the related genus Pseudotachea (Sacchi, I956) suggests that the polymorphism may be very ancient indeed. On a shorter time-scale, Goodhart (1956, I 958a) has shown that colonies may persist virtually unaltered in their phenotypic constitution for periods exceeding fifty years. Monomorphic colonies are rare. These facts suggest that much of the variation in Cepaea comes into the category of balanced, rather than transient, polymorphism (as defined by Ford, I 945).

For the maintenance of polymorphism there must be forces acting so that the rarer a gene becomes, the greater is its relative advantage. Such a situation occurs if the heterozygote tends to produce relatively more descendants than either homozygote. Another means of maintaining diversity may be provided by predators. If they come to associate common colour varieties with food, they may overlook the rarer forms, even if these stand out against their background. Evidence of effects of this sort is found in the works of Popham (I94 I, I 942) and Reighard ( I go8) on predation by fishes.

\section{DISCUSSION OF RESULTS}

Fig. 3 shows that the distribution of colour varieties in hortensis is not obviously related to the background from which the samples were taken. The collections with the lowest proportions of yellow shells, however, come from habitats that appear, subjectively, to be the most acid. The snails from Aston Rowant, Boarstall, Marcham, Elsfield and Derry Hill were all collected in piles of rotting vegetation. At Rockley Copse there is not a great deal of dead plant matter, but the area is flat and sandy, with patches of bracken. The Sonning sample seems to be an exception, having been taken under ivy on a 
chalk scarp. With the evidence available, the relation between acidity and the incidence of pinks and browns cannot be accepted as fact. It remains an interesting possibility.

Whatever may be the solution of the problem of the distribution of colour varieties, one thing remains certain. Cepaea hortensis, in the majority of colonies, has proportionately far fewer pinks and browns than has nemoralis. It is remarkable that, in spite of this, the samples seem to match their background.

On dark brown uniform backgrounds, in woods and under ivy, there are high percentages of banded forms with their bands fused together (see fig. 4). The effect of band-fusions is to make the shell appear dark brown in spite of the yellow ground colour, and to make it far less obvious against a woodland background.

In habitats with mixed vegetation (hedgerows and rough herbage) there is a preponderance of unfused banded forms. The disruptive effect of the bands tends to conceal the shells against the criss-cross of stems.

On grass, a uniform light green background, the yellow unbanded forms are least obvious, and most common.

It cannot be expected that the habitat classes will be as distinct in hortensis as they are in nemoralis. In the first place, hortensis is not at all common in woods, with the result that the woodland samples are very small and presumably subject to large sampling errors. Secondly, where hortensis does occur it tends to inhabit places where there is a good deal of ground vegetation and where the background is somewhat mixed. C. nemoralis, on the other hand, is commoner in woods and often lives where there is little or no ground cover, and where the background is very uniform.

It is therefore surprising how accurate is the agreement between the phenotype-frequency of hortensis and the nature of the background. Many colonies that appear, on the evidence of their position on fig. 4, to be aberrant do in fact come from unusual habitats. The beechwoods Knoll Down A and B have an unusually high proportion of yellow unbanded shells but, as I have already mentioned, they are unusually grassy, and the background in places is almost green. The Morgan's Hill downland colony is small in area, isolated and extremely exposed (on the crest of an $800 \mathrm{ft}$. hill). It has an unusually high percentage of fusions, but nine-tenths of these involve the lower two bands, which are not obvious when the snail is in its normal position on the ground. When a snail is climbing on vegetation the lower bands may be exposed; but at Morgan's Hill none of the plants were more than six inches tall. The distribution of different types of band-fusions will be discussed in a further paper.

The downland sample from Kingstone Coombes, which falls on fig. 4 among the beechwoods, was collected in a small patch of thistles about a hundred yards from a beechwood. Only nemoralis occurred in the surrounding grass. 
The Cowley-Chislehampton colony, which has no yellow unbanded shells, remains a puzzle. It is small in area, surrounded by colonies of nemoralis, and one of its phenotypes, pink unbanded with black lip, is not characteristic of the region (see below). It is conceivable that this colony resulted from the introduction of a very few individuals from elsewhere. The question must, however, be left open.

The Christmas Common hedgerow has a very high proportion of yellow unbanded shells, but it is surrounded by downland, which comes within fifty yards of it. Nearby woods seem to contain only nemoralis. It is therefore possible that the unusually high percentage of yellow unbanded shells may be due to gene-flow from the downland.

The explanation of aberrant colonies in terms of gene flow must not be accepted uncritically. It can only be used if the colonies are small in area and numbers, and if the only possible gene flow is from larger colonies of the type to which the smaller ones tend. These conditions are fulfilled in the colonies from Kingstone Coombes and Christmas Common, but there are certainly factors other than background that affect the distribution of phenotypes. Exposure, or something related to it, seems to be one (Clarke, in preparation).

In spite of the two or three colonies that seem not to match their background, the agreement among the other sixty-two or three is very good indeed (see fig. 4).

There are a number of other phenomena, for which complete explanations have not yet been found:

(a) Both albinos (var. arenicola) and pale-banded forms (var. lurida) appear to be more common among hedgerows and rough herbage than they are elsewhere (see tables I and 2, columns $(e)$ and $(f)$ ). If only the four major habitat classes are considered, these differences are significant at the 5 per cent. level.

(b) In the Oxford region, there are geographical differences in the distribution of certain phenotypes. There is an area of hortensis colonies near Abingdon, Berkshire-comprising about twenty square miles and bounded by the villages of Cumnor, Eaton, Fyfield, Marcham, Sunningwell and the town of Abingdon-in which pink shells with black lips occur, but in which yellow shells with black lips have not been found. Black-lipped pinks seem to be absent elsewhere in the Oxford region (excepting, that is, the colony on the road between Cowley and Chislehampton).

The oozoo phenotype appears to be restricted to an area between Rockley and Abingdon, and to another between Oxford and Brill.

Neither black-lipped pinks nor oo3oo have been found on the chalk Downs, or on the Ghilterns or Cotswolds.

\section{DIFFERENCES BETWEEN THE TWO SPECIES}

C. nemoralis and C. hortensis are very closely related, but nevertheless distinct, species. They can usually be distinguished by shell size, 
lip shape, body pigmentation and so on, but the only consistent differences are in the genitalia, particularly in the size and shape of the dart (see Taylor, 1914; Aubertin, 1927; Diver, 1940; and Lamotte, 1951). The chromosome numbers of the two species are identical (Perrot and Perrot, 1938). Hybrids have been obtained between them, but the fertility of crosses is very low (Lang, I9o8; Kleiner, 1913). Small numbers of naturally occurring hybrids have been reported (Boettger, I92I), and the possibility of some gene flow between the two species cannot be ruled out.

The polymorphisms in nemoralis and hortensis are probably determined by genes at homologous loci. In all the experiments so far recorded the dominance relations of the genes for colour and banding are the same in both species. Furthermore, the work of Cain and Sheppard (1954, I957) suggests that samples from natural populations can be a guide to linkage relations, at any rate in nemoralis. If this is true of hortensis, we may expect the genes for colour and banding to be linked in this species also, because in my samples the two characters are very significantly associated $(\mathrm{p}<0 \cdot 00 \mathrm{I})$. There is usually a deficiency of banded forms among the pinks and browns.

\section{CONCLUSIONS}

I have shown that the proportions of different phenotypes in populations of $C$. hortensis can be related to the habitat in which they live, and that this relation is necessarily the result of natural selection, probably of visual selection by predators. The same is true of $C$. nemoralis but, as we have seen, the response of populations to the environment differs in the two species.

If the genes controlling the polymorphisms of nemoralis and hortensis are homologous, as they appear to be, then the differences of response are, at first sight, puzzling. They can, however, be satisfactorily explained.

I have already pointed out that the two species have slightly different ecological preferences. It might be argued that the selective forces acting upon them are not strictly comparable, and that parallel variation is not to be expected. This can only partly be true. Mixed colonies are fairly common, and in these circumstances the distribution of phenotypes is not the same in each species. In fact, each responds to the environment in its own way (Clarke, in preparation). There might, of course, be differences in behaviour or micro-ecology within a single mixed colony. These could certainly affect the selective values of particular genes, but in visibly uniform habitats they are unlikely to alter the visual selective values. Cepaea hortensis occurs in a number of uniform beechwoods, in any part of which the brown unbanded variety would be visually superior to the yellow form with fused bands. The latter form is not completely brown; it shows a trace of yellow at the suture. Nevertheless it predominates. This suggests that the difference in response between the two species is due not merely to behavioural 
or micro-ecological preferences that cause the two species to occur on visibly different backgrounds.

It has often been pointed out that the action of particular genes cannot be considered apart from their genotypic environment (see, for instance, Mayr, I954, I955) and it seems very likely that, for reasons which have nothing to do with the appearance of the shells, the genes for brown and pink are, on the average, less advantageous against the genotypic background of hortensis than they are against that of nemoralis. In other words, non-visual environmental factors could affect the selective values of the genes in ways that depended upon the genotypic background, producing a low proportion of pinks and browns in most populations of hortensis, and a higher one in most populations of nemoralis. Such effects could alter the results of visual selection. In beechwoods, for instance, predation by thrushes would act upon nemoralis to increase the proportion of brown or pink unbanded shells. C. hortensis does not produce a high percentage of browns or pinks, probably for the reasons mentioned above, and therefore the same selective agent would increase the proportion of yellow shells with fused bands. The visible effect, an overall brown appearance, is very similar in both species, but the means of obtaining it are different. The range of variation is more circumscribed in Cepaea hortensis than it is in Cepaea nemoralis, but both species undoubtedly respond to the colour and uniformity of the background.

This study is regarded as an example of the importance of the genetic environment in determining the selective values of particular genes. It accounts for Lamotte's (I95I) inability to find a correlation between the phenotype frequencies of the two snails, and contradicts his thesis that selection is unimportant in determining the distribution of colour and banding varieties.

\section{SUMMARY}

I. Random samples were taken from a number of colonies of the polymorphic snail Cepaea hortensis Müll. Shells were scored for age, condition, colour and banding.

2. Analysis shows that the proportions of certain varieties can be related to the type of habitat from which the samples were taken. Colonies in woodlands tend to have a high proportion of banded shells with the bands fused together - a condition that gives an overall brown appearance which matches the background of brown leaf-litter. Colonies from grasslands, on the other hand, show a relatively high percentage of unbanded forms, which more closely resemble the uniform green background of grass. The differences between habitat classes are statistically very significant.

3. Works on the genetics of Cepaea are reviewed. Many of the colour and banding varieties are known to be genetically determined.

4. There is good evidence that the statistical differences between habitat classes are due to the action of natural selection, particularly 
of visual selection by predators, and that the variation comes into the category of balanced, rather than transient, polymorphism.

5. A comparison is drawn between the polymorphism of $C$. hortensis and that of the closely related species $C$. nemoralis, which has been studied by Cain and Sheppard. It is likely that the genes controlling the polymorphisms in the two species are homologous. The comparison shows that although populations of both snails respond to the influence of the habitat, they do so in very different ways. This difference of response is regarded as an example of the importance of the genetic environment in determining the selective values of particular genes.

6. The study provides an explanation of Lamotte's inability to find a correlation between the phenotype-frequencies of the two snails in mixed colonies, and contradicts his thesis that selection is unimportant in determining the distribution of colour and banding varieties.

Acknowledgments.-I am particularly grateful to Dr A. J. Cain, who has generously given his help and encouragement at every stage of the work. Messrs J. D. Currey, J. B. Gurdon, D. A. Jones, H. Wallace and Miss A. G. Jewkes have very kindly helped in the collection of samples. I am indebted to Dr P. M. Sheppard and Dr M. Williamson for much useful discussion and advice, and to Dr M. Williamson, Messrs J. D. Gurrey, J. B. Gurdon, and J. Murray for reading and criticising the manuscript. The work was carried out during the tenure of a Nature Conservancy Research Studentship at the Department of Zoology and Comparative Anatomy, Oxford. I am very grateful to Professor Sir Alister Hardy, F.R.s., for the help and facilities he has provided as head of the department.

\section{REFERENCES}

Aubertin, D. 1927. On the anatomy of land snails (Helicidae) Cepaea hortensis Müll. and Cepaea nemoralis L. Proc. Zool. Soc. Lond. A., 1927, 553-582.

Boettger, c. R. I92I. Ueber freilebende Hybriden der Landschnecken Cepaea nemoralis L. und Cepaea hortensis Müll. Zool. Fb. System., 44 (quoted by Lamotte, I94I).

Boettger, C. R. I950. Analyse einer bemerkenswerten Populationen der Schnirkelschnecke Cepaea hortensis Müller. Abh. braunschw. wiss. Ges., 2, I-I 2.

Boettger, G. R. I954. Zur Frage der Verteilung bestimmter Varianten bei der Landschneckengattung Cepaea Held. Biol. Zbl., 73, 318-333.

CAIN, A. J. 1953. Visual selection by tone in Cepaea nemoralis L. F. Conch., 23, 333-336.

CAIN, A. J., AND Sheppard, P. м. 1950. Selection in the polymorphic land snail Cepaea nemoralis. Heredity, 4, 274-294.

CAIN, A. J., And sheppard, P. m. 1954. Natural selection in Cepaea. Genetics, 39, 89-I 16.

CAIN, A. J., AND Sheppard, P. м. 1957. Some breeding experiments with Cepaea nemoralis L. J. Genet., 55, I95-I 99 .

DIver, G. 1929. Fossil records of Mendelian mutants. Nature, Lond., 124, 183.

DIVER, c. I 940 . The problem of closely related species living in the same area. In The New Systematics, ed. J. Huxley. O.U.P., London.

FORD, E. B. 1945. Polymorphism. Biol. Rev., 20, 72-88.

GOODHART, C. B. I956. Genetic stability in populations of the polymorphic land snail Cepaea nemoralis L. Proc. Linn. Soc. London, $167,50-67$. 
GOODHART, c. B. I958a. Genetic stability in the snail Cepaea nemoralis L., a further example. Proc. Linn. Soc. London, $169,163-167$.

goodhart, c. B. 1958b. Thrush predation in the snail Cepaea hortensis L. F. Anim. Ecol., 27, 47-58.

KLEINER, E. I9I3. Untersuchungen am Genitalapparat von Helix nemoralis, hortensis und einer weiteren Reihe von Lang gezüchteter Bastarde beiden Arten. Z. indukt. Abstamm.-u. VererbLehre, 9, $216-262$.

KOMAI, T., AND EMURA, s. 1955. Study of population genetics on the polymorphic land snail Bradybaena similaris. Evolution, 9, 400-418.

LAMOTTE, M. 195I. Recherches sur la structure génétique des populations naturelles de Cepaea nemoralis L. Bull. Biol. Suppl., 35, I-239.

Lамотте, м. I954. Sur la déterminisme génétique du polymorphisme chez Cepaea nemoralis L. C.R. Acad. Sci., 239, 365-367.

LANG, A. I 1904. Ueber Vorversuche zu Untersuchungen über die Varietätsbildung von Helix hortensis Müll. und Helix nemoralis L., Denkschr. med.-naturw. Ges. Jena., $I I, 439$.

LANG, A. I906. Ueber die Mendelschen Gesetze-, Art-, und Varietätsbildung, Mutation und Variation, inbesondere bei unseren Hain- und Gartenschnecken. Verh. Schweitz. Naturf. Ges. Luzerne (quoted by Lamotte, I95 I).

LANG, A. 1908. Ueber die Bastarde von Helix hortensis Müller und Helix nemoralis L. Einer Untersuchung zu experimentelle Vererbungslehre. Fetschr. Univ. Fena. (quoted by Lamotte, 1951).

LANG, A. I9II. Fortgesetzte Vererbungsstudien. Z. indukt. Abstamm.-u. VererbLehre, 5, 97-1 38 .

LANG, A. I9I2. Vererbungswissenschaftliche Miszellen. Z. indukt. Abstamm.-u. VererbLehre, 8, 233-283.

MAYR, E. 1954. Change of genetic environment and evolution. In Evolution as a Process, ed. J. Huxley, A. C. Hardy, E. B. Ford. George Allen and Unwin, London.

MAYR, E. 1955. Integration of genotypes : synthesis. Cold Spr. Harb. Symp. Quant. Biol., 20, 327-333.

MORRIS, D. 1954. The snail-eating behaviour of thrushes and blackbirds. Brit. Birds, 47, 33-49.

PERrot, J. L., AND PERrot, m. 1938. Monographie des Helix du groupe Cepaea; contribution à la notion d'espèce. Bull. Biol., 73, 232-262.

POPHAM, E. J. I94I. The variation in the colour of certain species of Arctocorisa (Hemiptera, Corixidae) and its significance. Proc. Zool. Soc. Lond. A., III, I $35^{-1} 7^{2}$.

POPHAM, E. J. 1942. Further experimental studies on the selective action of predators. Proc. Zool. Soc. Lond. A., I12, $105^{-11} 7$.

REIGHARD, J. I I908. An experimental field study of warning coloration in coralreef fishes. Publ. Carneg. Instn., I03, 257-325.

SACCHI, C. F. I956. Relazioni tra colori ed ambiente in popolazioni naturali spagnuole di Pseudotachea (Stylommatophora, Helicidae). Boll. Zool., 23, $46 \mathrm{I}-5 \mathrm{O}$.

SCHNETTER, M., AND SEDlmair, H. 1953. Verhaltens- und Resistenzunterschiede bei den polymorphen Bänderschnecken. Naturwissenschaften, 40, 515-516.

SEDlmair, H. I956. Verhaltens-, Resistenz-, und Gehauseunterschiede bei den polymorphen Bänderschnecken Cepaea hortensis Müll. und Cepaea nemoralis L. Biol. Zbl., 75, 281-313.

SHEPPARD, P. M. I95 I. Fluctuations in the selective value of certain phenotypes in the polymorphic land snail Cepaea nemoralis L. Heredity, 5, I 25-1 34 .

TAYLOR, J. W. IgI4. Monograph of the Land and Freshwater Mollusca of the British Isles, 3. Taylor, Leeds.

Wright, s. 1955. Classification of the factors of evolution. Cold Spr. Harb. Symp. Quant. Biol., 20, 16-24. 